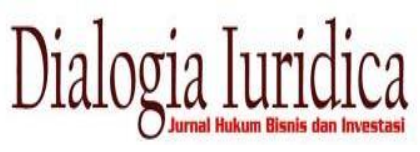

Volume 12 Nomor 1, November 2020, p.116-133

Faculty of Law, Universitas Kristen Maranatha

ISSN: 2085-9945 I e-ISSN: 2579-3520

Nationally Accredited Journal by SINTA

\title{
HARMONIZING RELATIONSHIPS OF CENTRAL GOVERNMENT AND REGIONAL GOVERNMENTS IN SHARE DIVESTMENT OF MINING COMPANIES
}

\author{
Demson Tiopan \\ Faculty of Law, Maranatha Christian University \\ demson.tiopan@maranatha.edu
}

Submitted: 2020-10-01: Reviewed: 2020-11-03: Accepted: 2020-11-20

\begin{abstract}
According to Article 1 number 8 Government Regulation no. 23/2010 concerning the Implementation of Mineral and Coal Mining Business Activities, share divestment is the number of shares that must be offered for sale to Indonesian participants. Share divestment efforts are carried out in accordance with the central government without involving local governments which are exploration areas for mining companies. The attitude of the central government towards regional governments does not reflect the legal objectives of divesting mining company shares. The writing of this article uses a normative legal research method, namely by examining secondary data in the field of law that exists as library data using deductive thinking methods and coherent truth criteria. To analyze this problem the author uses a theory derived from the law of Gustav Radbruc's treatment of the legal system proposed by Lawrence Friedman. The author finds that the legal norms that exist at the event do not want an unfair distribution, but in other legal norms there are provisions regarding special actions that can be taken by the central government, in the mining sector that can be used as a gap for the central government to monopolize. share divestment. The author suggests that the House of Representatives should formulate a law regulating the divestment of shares by the central government which also promotes and provides equal opportunities to local governments. If local government finances are unable to make efforts to divest shares of a mining company, the government must provide a divestment grant for its shares, even though the government loses its shares, but in principle the grant is used for regional prosperity.
\end{abstract}

Keywords: Divestment; Regional government; Central government 


\section{INTRODUCTION}

Nature is a gift from God given to humans to be managed as an effort to improve the quality of human life. Indonesia is one of the countries in the world that has given abundant natural resources, fom forest resources, sea and mineral mining materials. One of the resources that make Indonesia rich is mineral mining. Indonesian mining materials are one of the most abundant which are scattered in various regions in Indonesia. Certainly, these resources belong to the Indonesian people and are used for the prosperity of the Indonesian people as mandated by Article 33 paragraph 3 of the 1945 Constitution of the Republic of Indonesia that the land and water and natural resources contained therein are controlled by the state and used to the maximum extent possible for prosperity of the people.

In the effort to manage its natural resources, in fact that the Indonesia is unable to manage their natural resources. In an effort to manage these resources for the welfare of the people, the State of Indonesia needs people who are capable of managing it. On the other hand, many foreign countries want to manage Indonesia's natural resources. For this reason, finally Indonesia opened the access for other countries that wanted to exploit mineral mining resources in Indonesia.

We can see mining companies that have long been entrenched in Indonesian soil, such as Freeport, Inalum, and Newmont. These companies can operate in Indonesia by sharing the proceeds between the central, regional governments and these companies in fact, the distribution does not really benefit the government as the ruler of natural resources, it is the mining companies that get a bigger portion. In its development, the government has made many improvements in an effort to protect its natural resource wealth, one of which is by creating Work Contact. The Work Contract allows for a more profitable distribution than the previous methods.

In the Work Contract, there is an attempt by the government to slowly control mining companies managed by foreigners by divesting shares. Law Number 4 of 2009 concerning Minerals and Coal, makes divestment provisions a standard provision that applies generally to foreign share ownership in companies holding mining concessions (Mining Business License/IUP). According to Article 1 number 8 government regulations No. 23/2010 concerning the Implementation of Mineral and Coal Mining Business Activities, divestment of shares is the number of foreign shares that must be offered for sale to Indonesian participants. Investment is investment for one or more assets that are owned and usually have a long term with the hope of getting benefits in the future. The term divestment comes from the English translation, namely divestment. ${ }^{1}$ According to $\mathrm{H}$ Salim HS, as quoted by Erni Yoesry, there are also experts who use the term Indonesianization. Indonesianization is not only a transfer of profits, but more importantly a transfer of control

${ }^{1}$ Zainal Asikin, "Divestasi Saham Dalam Perspektif Keadilan (PT. NNT di Nusa Tenggara Barat)", Jurnal IUS, Volume 1, No.1, 2013, p.170. 
over the running of the company. ${ }^{2}$ Divestment is the sale of securities and / or government ownership either partly or wholly to other parties or is the disposal, release and reduction of capital. In this definition, divestment is defined as buying and selling. The subjects are the government and other parties (persons or legal entities) and the objects of sale, namely securities and government assets. ${ }^{3}$

The divestment of shares carried out by the central government does not have significant obstacles in terms of funding because it has large funds from the state budget and also the company's profit sharing. We also know that the mining company also operates not only in Indonesian territory but more specifically in certain regions which now have special autonomy. Regional Government areas that are used as mining objects, of course, have the worst impact and also share the results that are not proportional to the damage that occurs in the area. We know that the divestment of shares carried out by the central government does not involve the regions, such as the case of the divestment of shares in PT. Newmont Nusa Tenggara does not involve the Nusa Tenggara Barat regional government. ${ }^{4}$ In terms of the area that is used as the object and also the limited economic resources, the regional government should have the right to get the divestment of shares that is attempted by the central government. Because we know that all of this is an effort for the welfare of the people, especially the people of Nusa Tenggara Barat.

Article 18A paragraph 2 of The 1945 Constitution states that financial relations, public services, utilization of natural resources and other natural resources between the central government and regional governments are regulated and implemented in a fair and balanced manner based on law. Law Number 23 of 2014 concerning Regional Government Article 14 paragraph (1) The implementation of Government Affairs in the forestry, maritime affairs, and energy and mineral resources sectors is divided between the Central Government and the Provincial Regions. In this case it is clear that in the management of natural resources the position of the central government must be fair to regional governments. Gustav Radbruch ${ }^{5}$ stated three basic values which are the goals of law, namely for justice, legal certainty, and utility. Lawrence M. Friedman stated that the legal system consists of the structure, substance, and culture of law. ${ }^{6}$ Based on the problems that have been stated above, the author will provide a limitation of the problem in this paper. The problem formulation to be discussed in this paper is how should the central

\footnotetext{
2 Erny Yoesry, "Divestasi PT. Freeport Indonesia", Jurnal Hukum \& Pembangunan Tahun ke- 49, No. 1,2019, p .160.

${ }^{3}$ Nelsa Nurfitriani Pratama,et,al, "Pengaturan Kewajiban Divestasi Saham Dalam Perusahaan Modal Asing Di Bidang Pertambangan Menurut PP. No 77 Tahun 2014 Tentang Pelaksanaan Kegiatan Usaha Pertambangan Mineral Dan Batubara”, Diponegoro Law Review, Volume 5, No. 2, 2016. p 2.

${ }^{4}$ Republika, 2015 , NTB minta pusat tegas soal Divestasi saham Newmont, http://www.republika.co.id, accessed on 01 Oktober 2020.

${ }^{5}$ Satjipto Rahardjo, Pemanfaatan Ilmu-Ilmu Sosial Bagi Pengembangan Ilmu Hukum, Yogyakarta: Genta Publishing, 2010, p.30.

${ }^{6}$ Ishaq, Dasar-dasar Ilmu Hukum, Jakarta: Sinar Grarafika, 2008, hlm.183.
} 
government engage with regional governments in divesting shares in an effort to achieve the objectives of the law?

\section{DISCUSSION}

\section{Justice: Substance}

Justice is one of the most discussed objectives of law in the history of legal philosophy. ${ }^{7}$ Aristotle argues that justice is a balance between rights and obligations, humans are supporters of rights and obligations. Whereas the Sophists in Greece say justice is what benefits those who are stronger. ${ }^{8}$ According to Hans Kelsen Justice in the sense of legality is a quality that is related not to the content of a positive legal order, but with its application. ${ }^{9}$ In the perspective of central and regional relations, of course Aristotle's opinion cannot be fully implemented, because of the limited regional resources, both in terms of humans, nature and others which make it an imbalance between rights and obligations.

Law (which is translated from the word "law" in English) according to Herman J. Pietersen is a normative building. In this sense, law is conceptualized as an instrument of the state or policies concerned with justice, with rules of conduct to regulate human behavior. So according to this view, law is an instrument to uphold justice in the form of a code of conduct with its main function to regulate human behavior. Talking about law is synonymous with talking about relationships between humans. ${ }^{10}$ In the context of the relationship between the central and regional governments, discussing relations between governments is talking about justice. The understanding of justice may vary depending on which side we are talking about. In this paper justice is defined as a willingness that is permanent and perpetual to give each region what it should receive. The role of law in matters of justice is to bring the idea of justice into concrete forms so that it can benefit relations between central and regional governments.

Therefore, it is understandable that Herman J. Pitersen's statement states that the objectives of law are: to serve justice, to preserve society's systemic integrity and stability and, ultimately, to promote the general good, well-being. ${ }^{11}$

Natural Law theories from Socrates to Francois Geny, still maintain justice as the crown of law. Natural Law Theory prioritizes "the search for justice". ${ }^{12}$ Objective guidelines come from ground norms (basic norms). Groundnorm is like a presupposition

\footnotetext{
7 Dardji Darmohardjo, Shidarta, Pokok-Pokok Filsafat Hukum: Apa Dan Bagaimana Filsafat Hukum Indonesia, Jakarta: Gramedia Pustaka Utama., 2006, hlm.155.

${ }^{8}$ Moh.Mahfud MD, Politik Hukum di Indonesia, Jakarta: Rajawali Pers, 2012, hlm. 21.

9 Hans Kelsen, Teori Umum Tentang Hukum dan Negara, Bandung: Nusa Media, 2011, hlm.17.

${ }^{10}$ FX. Adji Samekto, Justice Not For all, Yogyakarta: Genta Press, 2008, hlm..6-7.

${ }^{11}$ Ibid.

12 Teori Keadilan: Theo Hujibers, Filsafat Hukum Dalam Lintasan Sejarah, Yogyakarta: Kanisius, 1995, hlm.196.
} 
about the order to be realized in living together (in this case is the State). Groundnorm is a transcendental-logical requirement for the application of all legal systems and all positive legal systems must be guided hinarchically on ground norm. ${ }^{13}$ Grundnorm in the Indonesia is defined as the 1945 Constitution of the Republic of Indonesia. In Article 18 A paragraph 2 of the 1945 Constitution of the Republic of Indonesia states financial relations, public services, utilization of natural resources and other natural resources between the government. central and regional governments are regulated and implemented in a just and harmonious manner based on law.

In regional laws and regulations, it is emphasized that the implementation of regional government is based on broad, real and responsible autonomy that is focused on the regency/city area. Thus, the implication is the size and number of governmental affairs that are regulated and administered by each regional government. ${ }^{14}$ This can be understood because in the science of forming laws and regulations, the law is seen from the perspective of the legislators. Formers formulate or form legal regulations or regulate community life for the future within a certain period. ${ }^{15}$ So that in this case the legislators must see the prevailing norms.

Law Number 23 of 2014 concerning Regional Government Article 14 paragraph (1) states that the implementation of Government Affairs in the forestry, maritime affairs, and energy and mineral resources sectors is divided between the Central Government and Provincial Regions. This is the norm that regulates the distribution that must be fair for the central and regional governments, including divestment of shares. The financial balance between the Government and regional governments is a system of financial distribution that is fair, proportional, democratic, transparent and accountable in the framework of funding the implementation of decentralization, taking into account the potentials, conditions and needs of the regions as well as the amount of funding for the implementation of deconcentration and assistance tasksThis division is of course related to the divestment of shares by the Central Government.

The decentralization and regional autonomy policies as mandated by Article $18 \mathrm{~A}$ paragraph 2 of the 1945 Constitution of the Republic of Indonesia and other provisions, are very important, especially to ensure that the national integration process can be properly maintained. The previous policies of decentralization and regional autonomy were felt to be unfair, especially in terms of authority and financial relations between the government and regional governments. ${ }^{16}$

\footnotetext{
${ }^{13}$ Bernard L. Tanya dkk, Teori Hukum, Strategi Tetrib Manusia Lintas Ruang dan Generasi, Surabaya: CV. Kita, 2010, hlm. 127.

${ }^{14}$ Ibid, hlm. 38.

${ }^{15}$ Sudikono Mertokusumo, Penemuan Hukum, Yogyakarta: Liberty, 1996, hlm. 14-15.

${ }^{16} \mathrm{Ibid}, \mathrm{hlm} .3$.
} 
Regional government laws are the basis for each region to carry out household affairs in accordance with the capacity and needs of regional development. Regional development is an integral part of national development with the principle of autonomy. As autonomous regions, regions have the authority and responsibility to carry out the interests of society based on democratic principles. To support the implementation of regional autonomy, broad, tangible, and responsible authority is needed within the corridors of the unitary state. ${ }^{17}$ For this reason, there is a need for norms regulating the transfer of authority to regional governments to also divest shares carried out by the central government. If regional governments do not have adequate financial resources, the central government is obliged to assist regional governments.

\section{Justice: Structure}

Talking about justice, we generally think of it as individual justice, namely justice that depends on the good or bad will of everyone. ${ }^{18}$ This can sometimes be said to be appropriate if we look at the current situation and condition of law enforcement and enforcement officials. It is as if the central government is the one who determines whether an action is taken against the regional government is just.

It is not unusual, that the role of the central government is very necessary in upholding justice because it has an important role in creating a system or a conducive socio-political structure from upstream to downstream. Sony Keraf argues about the structure of justice, that a fair system or structure is political openness on the part of the government to be prosecuted based on existing rules of justice. ${ }^{19}$ This is the consequence of the imbalance between legal norms and concretisation in the field. The times are not balanced with legal norms, so the existing regulations cannot accommodate them holistically. True justice is not realized because there has been a shift in the value between individual needs and universal needs. According to Taylor, the controversy surrounding the theory of justice is not only concerned with the criteria of justice and what is done to be fair, but also concerns the question of distributive justice. The continuation of the principle of distributive justice is related to the conception of what is good for humans, especially differences in understanding of the position of individuals in society to realize good values. $^{20}$

Enforcing justice in this case is carried out through court bodies. Conception is rooted in the desired condition of society. Usually, this conception is only stated explicitly when members of society are faced with injustice. Justice is not a status but a process, therefore

\footnotetext{
17 Ibid, pg.40.

${ }^{18}$ Antonius Atoshoki, dkk., Relasi Dengan Sesama, Jakarta: PT Elex Media Komputindo, 2002, hlm. 332.

${ }^{19}$ Sony Keraf, Cetakan 16, Pustaka Filsafat Etika Bisnis, Tuntunan dan Relevansinya, Yogyakarta: Kanisius, 2012, hlm.146.

${ }^{20}$ Lemhanas, Keadilan Sosial, Jakarta: Gramedia Pustaka Utama, 2005, hlm.104-105.
} 
we will understand it better, if we also see the manifestation of justice in a process and through the injustice that is revealed during the process, we will actually catch what is actually called fair. The justice that is aspired to come not only from the regulations made but also by the apparatus.

Mining companies are a source of regional income, which should be prioritized for regional welfare. The apparatus authorized to enforce and enforce the law in this case can be interpreted as the central government. The central government as the highest authority can treat regional government fairly as stated in the provisions of the law. This effort is done to improve the welfare of the local community.

According to Bagir Manan, decentralization is any form or action of radiating power or authority from an organization, position, or official. ${ }^{21}$ The mechanism for the transfer of authority to the regions is carried out in two ways: ${ }^{22}$

1. Full surrender, meaning that both the principles (principles) and how to carry out the duties (the work) that is submitted, are all handed over to the regions (autonomy rights).

2. Incomplete Submission, meaning that it is only about how to run it, while the principles (principles) are determined by the Central Government itself.

The current decentralization is essentially a complete devolution of certain sectors which are not under the central authority. Utilization of natural resources should be one of the uses that can become a regional monopoly. However, in fact this is a monopoly of the central government. Basically, it is good to balance regional finances that are not rich in natural resources and regions that are rich in natural resources. However, it is necessary to know that regions that have mining resources will also be depleted, so it needs to be supported by the central government when the resources run out. As a manifestation of independence as the principle of regional autonomy, the central government should prioritize divestment of shares by the Regional Government for the long-term interests of the region.

The government should not act like a static machine but as a creative institution to guide and serve the people. This task can be carried out, if the law is given the freedom to give interpretation. Interpreting is part of that guiding and serving duty. The government will be trusted by the community if it creates policies that support local communities. The central government must provide the proceeds from divestment of shares to regional governments in an effort to make the people in the area where the mine is managed prosper. In order to create a sense of trust in his own government.

\footnotetext{
${ }^{21}$ Bagir Manan, Menyongsong Fajar Otonomi Daaerah, Yogyakarta: Pusat Studi Hukum FH UII, 2001, hlm. 10 .

${ }^{22}$ Syaukani Hr, dkk, Otonomi Daerah dalam Negara Kesatuan, Yogyakarta: Pustaka Pelajar, 2002, hlm. .68.
} 
The new culture of law enforcement system departs from the principle of "law enforcement to serve and protect the interests of the people" instead of emphasizing "system independence". Component independence is only a tool, not a goal. A big goal is a social goal to provide as much justice as possible to society or the people. Such changes in philosophy will undoubtedly have an impact on the restructuring of the law enforcement system, even to the change in the culture of prosecutors and judges, only differences. ${ }^{23}$

\section{Justice: Legal Culture}

According to Gustav Radbruch, the objectives of law are justice, certainty and benefit. Justice must have the first and foremost position of legal certainty and benefit. Historically, according to Gustav Radburch, the goal of legal certainty was at the top of the list among other objectives. However, after seeing the fact that with his theory, Germany under Nazi rule legalized inhumane practices during World War II by making laws legalizing the practices of war atrocities at that time. Gustav Radbruch finally corrected his theory above by placing the objective of justice above other legal objectives ${ }^{24}$

The law is a system, which means that the law is an order, is a complete unit consisting of parts that are closely related. In other words, the legal system is a unit consisting of elements that interact with each other and work together to achieve the objectives of this unity. ${ }^{25}$ Substance, Structure and Culture of Law are elements of the legal system, so inevitably all of these become areas of work simultaneously as areas for developing theories of law. Legal theory can be developed both in the area of legal substance and in the area of legal structure and culture itself. ${ }^{26}$

According to Bruggink, the objects of the sociology of law at the first level are realities in society, and only at the second level are legal rules, which in one way play a role in the reality of society. ${ }^{27}$ Legal science has a close relationship with its people. It is difficult to understand the law of a nation properly, if the law is released from the environment and habitat, in this case the society in which the law exists and is implemented. ${ }^{28}$ In fact, the law does not overshadow change, without change, the law will be left behind by society. Resisting these changes will only cause the law to commit suicide because it is of no use to society. ${ }^{29}$

Regional autonomy is a manifestation of the legal culture that exists in Indonesian society, Indonesia stands because of the agreements of all regions in Indonesia to form a

\footnotetext{
${ }^{23}$ Satjipto Rahardjo, Hukum Progresif, Yogyakarta: Genta Publishing, 2009, hlm.145.

${ }^{24}$ Sudikno Mertokusumo, Mengenal Hukum, Yogyakarta: Universitas Atma Jaya Yogyakarta, 2010, hlm.161.

${ }^{25}$ Loc. Cit, hlm.122.

${ }^{26}$ Bernard L. Tanya, Op.Cit, hlm.11.

${ }^{27}$ Salman, Otje dan Susanto, Anton F, Teori Hukum: Mengingat Mengumpulkan, dan Membuka Kembali, Bandung: Refika Aditama., 2013, hlm. 61.

${ }^{28}$ Satjipto Rahardjo, Op.Cit, hlm. 27.

${ }^{29} \mathrm{Ibid}, \mathrm{hlm} .59$.
} 
unitary state. Of course, this is without neglecting the importance of the region. The relationship between the Central and Regional Governments continues to develop from time to time in line with changes in society in the regions. We know that the existence of special areas is a manifestation of the legal culture in the region. Central and regional economic relations cannot be separated from the development of legal culture in local communities. There is not a single local community who does not want to enjoy the results of their wealth of natural resources.

The relationship between central and regional finance is seen as determining the independence of autonomy. But what is commonly argued about is the "small" amount of money owned by regions compared to those owned by the center. According to Muchsan, the main principle of decentralization (autonomy) includes three things, namely: ${ }^{30}$

1. Sharing Power

2. Distribution of income

3. Empowering (independent regional government administration)

Based on this premise, the core of central and regional financial relations is "financial balance". The balance is none other than increasing the regional revenue so that the regional financial granary can provide more. ${ }^{31}$ The aim is to fulfill a sense of justice in society so that there is economic equity.

For this reason, the proper form of relations between the central and regional governments in financial matters, especially in share divestment. This must first be returned to the basic notion of autonomy, namely independence. Regions must have the flexibility to decide for themselves how to organize and manage their household affairs. Enlarging regional revenue sources is one way that must be done. Prioritizing regions to make efforts to divest shares is the method. However, this is not fully possible because regional finances are not fully capable of making efforts to divest shares. Therefore, the definition of a balance between central and regional finances should not only be interpreted as enlarging regional revenue sources, but the central government strives to increase the number of these regional revenue sources.

\section{Benefits: Substance}

Legislations made regarding regional autonomy are a manifestation of efforts to achieve the welfare of the people in the regions and also a fair distribution. As said by Sudikno Mertokusumo, the existence of law aims to provide security and order and ensure the welfare that the community receives from the State as a social umbrella. The rule of law in

\footnotetext{
30 Muchsan, Sistem Pengawasan Perbuatan Aparat Pemerintah dan Peradilan Tata Usaha Negara, Yogyakarta: Liberty, 2000, hlm. 9.

${ }^{31}$ Bagir Manan, Op.Cit, hlm. 40.
} 
addition to the interests of humans against the dangers that threaten them, also regulates relationships between humans. ${ }^{32}$

However, the laws and regulations that were made did not make the people in the area prosperous. For this reason, a breakthrough law is needed, meaning that it can accommodate the interests of society which are regulated by legal norms. According to Johnson, the legal teachings that can be applied, in order to create a correlation between law and society, namely social law are stronger and more advanced than the teachings created by individual law. ${ }^{33}$ The articulation of this law will create laws in accordance with the ideals of society. Therefore, the estuary of law is not only justice and legal certainty, but also aspects of benefit must be fulfilled. Utilitarianists introduce a third legal goal, besides justice and legal certainty. The purpose of the law according to utilitarianists is the benefit of all people. ${ }^{34}$

According to montesquie a legal technocrat, legislators in shaping the law must be like a healer who diagnoses a patient's illness and then prescribes it. ${ }^{35}$ This can be applied in legal efforts to bring benefit to as many people as possible. We know that one of the "diseases" that exist in this nation is poverty which must be "cured" by laws that bring benefits to as many people as possible in Indonesia. One form of this is the divestment of shares by the Regional Government.

Law is the lifeblood of a nation to achieve the ideals of a just and prosperous society. For Hans Kelsen, law itself is a sollenskategorie (necessity category) rather than a seinkategorie (factual category). What it means is that the law is constructed as a necessity which regulates human behavior as a rational being. In this case what is questioned by law is not what the law ought to be but what the law is. ${ }^{36}$

According to Sudikno Mertokusumo, the public expects benefits in implementing or enforcing law. Law is for humans, then law enforcement or law enforcement must provide benefits or benefits to society. Do not let it be that because the law is implemented or enforced, there will be unrest within the community itself. ${ }^{37}$

Law aims at "the greatest happiness of the greatest number". The objectives of legislation should seek to achieve four objectives:

1. To provide subsistence;

2. To provide abundance;

3. To provide security;

\footnotetext{
${ }^{32}$ Sudikno Mertokusumo, Cetakan ke 1, Teori Hukum, Yogyakarta: Universitas Atma Jaya, 2011, hlm.16.

${ }^{33}$ Alvin S. Johnson, Cetakan ke 3, Sosiologi Hukum, Jakarta: Asdi Mahastya, 2006, hlm.204.

34 Shidarta, Dardji Darmohardjo, Pokok-Pokok Filsafat Hukum: Apa dan Bagaimana Filsafat Hukum Indonesia, Jakarta: Gramedia Pustaka Utama, 2006, hlm.160.

${ }^{35}$ Montesquieu, Cetakan Ke 6, The Spirit of Laws, Bandung: Nusa Media, 2013, hlm.17.

${ }^{36}$ Hans Kelsen, Teori Hukum Murni, Bandung: Nusa Media, hlm.15.

${ }^{37}$ Sudikono Mertoksumo, Op.Cit, hlm.161.
} 


\section{To attain equility. ${ }^{38}$}

In connection with the stated benefits, According to Anggito Abimanyu, from an economic point of view, autonomy means giving the widest possible right to the region to manage economic resources. With autonomy, community and regional empowerment will be faster. The gap between the Central and the Regions becomes thin. If regions are given the maximum autonomy possible, rich regions will subsidize poor regions, because there are still some who distribute the economic pie. ${ }^{39}$

In developing the characteristics of decentralization and regional autonomy, there are at least two preconditions that must be considered. First, given the authority to make decisions on matters relating to the region. Second, given the freedom to control and transfer the various potential sources of the region concerned. Of the two benchmarks, the first is more widely adopted, while the second is starting to be abandoned. ${ }^{40}$ For Indonesia, the implementation of the second prerequisite is very difficult to do, because the potential and natural resources in each region are different, while the central government is obliged to strive for national economic equality. This is also the central government's effort in defending the unitary state. So that in practice most financial resources are collected from the central government to be distributed back to regional governments.

In Law Number 23 of 2014, it is emphasized that the regional government in implementing government affairs has a relationship with the central government and with other regional governments. This relationship includes the relationship of authority, finance, public services, utilization of natural resources and other natural resources. Financial relations, public services, utilization of natural resources and other natural resources give rise to administrative and territorial relations between levels of government. Even though the law has so ideally regulated the basics of the relationship between the central and regional governments, in practice the central government does not realizing the legal objectives put forward by Jeremy Bentham that the purpose of law is to give humans the greatest possible happiness. ${ }^{41}$

The formation of statutory regulations which in fact is a form of legal certainty prioritizes justice as mandated by Article 18 of the 1945 Constitution of the Republic of Indonesia. as we know there is the principle of lex Superior derogete legi Inferior, which means that the higher provisions override the lower provisions. The government in carrying out its policies must pay attention to this principle so that in the implementation of the law, especially in the distribution of regional rights, in this case the divestment of shares can be accommodated in the existing norms in accordance with the common interest in the efforts

\footnotetext{
${ }^{38}$ Ibid, hlm. 76-78.

${ }^{39}$ Ni'matul Huda, Otonomi Daerah, Yogyakarta : Pustaka pelajar, 2005, hlm.64.

${ }^{40}$ Ibid, hlm. 92.

${ }^{41}$ Ishaq, Op.Cit, hlm.9.
} 
of the regional government to provide benefits to as many people as possible. By providing these benefits, the community will be prosperous and can create happiness.

\section{Benefit: Structure}

According to Apeldoorn, the law also does not prioritize justice but prioritizes the benefit, this is because of legal norms regarding evidence and expiration. That the law merely demands useful things or is in accordance with utility (utilization theories.). This teaching is mainly formulated as follows 1 . The law wants to guarantee the greatest happiness for the greatest number of human beings (eudaemonism or utilitarianism) 2. This view is one-sided because the law is only in accordance with usability or usefulness if the law pursues justice as much as possible. So, the purpose of law is a peaceful and just society order. To remove the view of justice from the law means equating law with power. ${ }^{42}$

In a modern rule of law, the function of the Government (in a broad sense) is not limited to just being a guardian of order (nachtswakerstaat). However, it also has an obligation to improve the welfare of its people (a country with a welfare state type). Indonesia is part of it, therefore the policies of the President and his Minister as representatives of the central government must provide benefits to the community in the regions.

In the 1945 Constitution (preamble, fourth paragraph) it is stated that the aim of the formation of the Indonesian state is to protect the entire Indonesian nation and to advance public welfare, to educate the nation's life and to participate in implementing world order based on independence, eternal peace, and social justice. From this it is even more obvious that the goal of the State is to prosper society based on social justice. ${ }^{43}$

One of the efforts to improve the welfare of the Indonesian people is the financial relationship between the center and the regions regarding distribution. This relationship involves the division of responsibilities for carrying out certain activities between levels of government and the sharing of sources of revenue to cover expenses resulting from these activities. The main purpose of this relationship is to achieve a balance between these various divisions, how to align the potential and resources of each region. ${ }^{44}$

Financial tools that can cover such a role for regional governments include:

1. Regional governments are empowered to collect taxes which can generate large amounts of income and to determine their own tax rates;

2. Sharing of national tax revenue between the central government and regional governments;

\footnotetext{
42 Apeldoorn, Van, Inleiding tot de Studie van Het Nederlandse Recht, Terjemahan M. Oetarid Sadino, Pengantar Ilmu Hukum, Jakarta: Noordhoff-Koff, 1958, hlm.15-16.

${ }^{43}$ Muchsan, Beberapa Catatan Tentang Hukum Administrasi Negara dan Peradilan Administrasi Negara di Indonesia, Yogyakarta: Liberty, 1981, hlm.3.

${ }^{44}$ Adrian Sutedi, Implikasi hukum atas sumber pembiayaan daerah dalam kerangka otonomi daerah, Sinar Grafika, Jakarta, 2009, hlm.90.
} 
3. General assistance from the central government without control by the central government over its use $\mathrm{s}^{45}$

Basically, a lot of general assistance from the central government has been carried out, such as allocation funds for regions. But in fact, the regions have not yet felt prosperity, there are still many people who do not work. For this reason, general assistance such as share grants from the divestment of the central government can be made.

According to Adrian Sutendi's view, regional government is basically an institution to provide certain services for the region, and as an appropriate tool to make up for the cost of providing services that are solely beneficial to the region. The objectives of the regional government are administrative and economic in nature. ${ }^{46}$ From an economic point of view, the efficiency and effectiveness of the use of natural resources could be greater if the central government also looked more at the interests of regional governments in the long term. Divestment of shares that prioritizes regional interests can benefit the region in the long run because natural resources in the area especially mineral resources will inevitably run out for that when these natural resources run out. Regional governments need large funds to develop their regions. The effort to divest shares is one of the policies of the President as the state apparatus to protect these interests.

Perhaps the Central Government Policy of not giving the share divestments to the regional government and emphasizing the role of the central government. Due to several things as stated by Adrian Sutend ${ }^{47}$ First, concerns about national unity, and concerns about divisive forces that inevitably emerged from the volatility of the early years after independence. Second, related to the first factor, the problem of maintaining political balance and justice in the distribution of resources between regions, especially between the island of Java, which is inhabited by the largest part of the Indonesian people, and areas outside Java, which generate a lot of revenue from exports and have the largest share of the country's economic potential.

In the interests of the local people, the government should make rules regarding divestment of shares. State apparatus such as the Ministry of Natural Resources and Energy, the Ministry of Finance as implementers of the Law and play a major role in relations with regional governments are expected to also play a role in advancing the local people. However, the President as a representative of the central government can directly make policies that are in favor of the local people.

\section{Benefit: Legal Culture}

Various definitions of law as a legal system are put forward, among others, by Lawrence M. Friedman that law consists of structural, substance and culture components. The

\footnotetext{
${ }^{45} \mathrm{Ibid}$, hlm. 91.

${ }^{46}$ Ibid.

${ }^{47}$ Ibid.
} 
component of culture, which consists of values, attitudes, perceptions, custom, ways of doing, ways of thinking, and opinions that affect the operation of law by Lawrence M. Friedman, is called legal culture. This legal culture serves as a bridge that connects legal regulations with the legal behavior of the entire community. ${ }^{48}$

Various views of legal experts see between law and legal sociology (social change) and other aspects. Two opposing views of law and social change, namely the view that law is a tool for social engineering, is dominated by Roscoe Pound. Meanwhile, another view says that society determines the law, not the other way around, which was driven by Cochrane. ${ }^{49}$ Humans individually or collectively who are members of the community play a major role in carrying out the law. Legal awareness and culture as a stimulant for the implementation of regulations established by regulators. The constitution as the basis of course holds great hopes from the public to protect it from arbitraryness. However, if you look at the real conditions in the field of law, it seems that one is under a ruler who is actually a supreme above anyone without paying attention to the public. It is known that the law that must adhere to the principle of equality has to face a very different reality. ${ }^{50}$ The reality of society is basically already listed in our constitution, namely the 1945 Constitution of the Republic of Indonesia. In the 1945 Constitution of the Republic of Indonesia, the policy on relations between the central and regional governments must be carried out fairly in which regions are given the right to regulate their own regions.

With autonomy, a mechanism will be created whereby the regions can achieve a number of political and economic functions for the national government, as well as more equitable relations of power and the use of natural resources so that regions will have confidence and will eventually be integrated into the national government. With autonomy, the economic bureaucracy process will be faster and ultimately regional development will be accelerated. According to Satjipto, the system of regulations in society is a conditio sine qua non for the running of economic activities. Economic life presupposes the existence of a certain social order, and in that social order economic activities are carried out. ${ }^{51}$ So that the condition of the community also affects the course of economic activities even when the regional government is divesting shares.

The shift in duties, functions and responsibilities of government institutions gave birth to the concept of handing over of authority or better known as decentralization. Conceptually, decentralization is basically the delegation or handover of power or authority in a certain area vertically from institution/higher officials to institutions/functionaries

\footnotetext{
${ }^{48}$ Esmi Warassih, Pranata Hukum, Semarang: Badan Penerbit Universitas Diponegoro, 2011, hlm. 24.

49 Dominikus Rato, Cetakan ke 2, Hukum Dalam Perspektif Konstruksi Sosial, Yogyakarta: Laksbang Mediatama, 2009, hlm. 236.

${ }^{50}$ Sartjipto Rahardjo, Penegakan Hukum Suatu Tinjauan Sosiologis, Yogyakarta: Genta Publishing, 2009, hlm. 61.

${ }^{51}$ Rahardjo Satjipto, Membangun dan Merombak Hukum Indonesia, Yogyakarta: Genta Publishing, 2009, hlm. 82-83.
} 
subordinates so that those who are entrusted/delegated with certain powers have the right to act on their own behalf in certain matters. ${ }^{52}$ Thus, decentralization is one of the pillars of a unitary state and a democracy. But it is meaningless if the implementation is not carried out consistently and seriously. ${ }^{53}$ In fact, this does not happen, the legal culture that occurs is that the central government is more dominant in regulating the use of natural resources in the regions. Especially mining, oil and minerals. In the case of divestment of shares, the central government always divestes in the interest of the central government. In the end, this is detrimental to the people in the regions which will backfire on the central government itself.

For that we need local community participation. Public participation is defined as an active way of determining community participation, both individually and in groups, actively in determining public policies or laws and regulations. That participatory public decision-making is useful so that these decisions truly reflect the needs, interests and desires of the wider community. ${ }^{54}$ Community participation in the Inalum and Newmont Mining Company Divestment Case is very prominent, especially through representative institutions where the local community wants the divestment of shares. Even the regional government is trying to divest shares by involving the private sector. However, involving the private sector does not benefit the local community. For this reason, the central government must accommodate the aspirations of the local community by providing assistance and granting divestment of central government shares to regional governments. So that people in the area can also get prosperity from the natural resources in the area.

\section{CONCLUSION}

The implementation of Regional Autonomy in this case is reflected in the example of the share divestment case not in line with the objectives of the law stated by Gustav Radbruch. Gustav said that the purpose of law is certainty, justice and benefit. From the results of the author's research that the goal that can be realized is the certainty where the relationship between the central government and regional government is regulated in the Laws and Regulations, namely Article 18 A paragraph 2 of the 1945 Constitution, Law Number 32 of 2004 concerning Regional Autonomy and Law Number 23 of 2014 regarding Regional Government.

Legal norms that exist in statutory regulations require the realization of the goal of justice in the relationship between the central and regional governments. However, in practice the central government as one of the implementers of laws related to regional autonomy does not carry out relations with regional governments based on the principle of

\footnotetext{
52 Ansi Mustari Pide, 1999, Otonomi Daerah dan Kepala daerah Memasuki Abad XXI, Jakarta:Gema Media Pratama, hlm. 33.

${ }^{53}$ Sudi Fahmi, Bunga Rampai Pemikiran Hukum di Indonesia, Yogyakarta:FH UII Press, 2009, hlm.132.

${ }^{54}$ Saldi Isra, Pergesaran Fungsi Legislasi, Jakarta: Rajawali Pers, 2013, hlm.282.
} 
justice. The divestment of mining company shares by the central government became the monopoly of the central government. In fact, this area is the one affected by the dredging of natural resources, both mining and minerals. There are no laws and regulations that are too detailed in terms of dealing with the relationship between the Central Government and Regional Government. Much of the literature that explains more about solving this problem involves more politics. Of course, the legal culture of the local community wants to expect justice. The existing norm embodies a culture of justice in the local community, but this is not fully realized, especially in terms of divestment of shares in mining companies.

The existing norms also require that the aim of holding regional autonomy is to solve Indonesia's local problems, in the form of poverty and unequal development, the low quality of life of the people and problems of human resource development. Indeed, many efforts have been made, but divestment of shares has not been something that the regional government must do first. To advance local communities, it is appropriate for the central government to offer divestment shares to regional governments. This is done so that the purpose of the benefit of the law can be realized, where local people feel the natural products that have been dredged and this can also be used as capital when these natural resources are exhausted, and the area has no other resources.

\section{REFERENCES}

\section{Books}

Adrian Sutedi, Implikasi hukum atas sumber pembiayaan daerah dalam kerangka otonomi daerah, Sinar Grafika, 2009.

Alvin S. Johnson, Cetakan ke 3, Sosiologi Hukum, Jakarta: Asdi Mahastya, 2006.

Ansi Mustari Pide, Otonomo Daerah dan Kepala daerah Memasuki Abad XXI, Jakarta: Gema Media Pratama, 1999.

Antonius Atoshoki, dkk., Relasi Dengan Sesama, Jakarta: Elex Media Komputindo,2002.

Apeldoorn, Van Inleiding tot de Studie van Het Nederlandse Recht, Terjemahan M. Oetarid Sadino, Pengantar Ilmu Hukum, Jakarta: Noordhoff-Koff, 1958.

Bagir Manan, Menyongsong Fajar Otonomi Daaerah, Yogyakarta: Pusat Studi Hukum FH UII, 2001.

Bernard L. Tanya dkk, Teori Hukum, Strategi Tetrib Manusia Lintas Ruang dan Generasi, Surabaya: CV. Kita, 2010.

Dardji Darmohardjo, Shidarta, Pokok-Pokok Filsafat Hukum: Apa Dan Bagaimana Filsafat Hukum Indonesia, Jakarta: Gramedia Pustaka Utama, 2006.

Dominikus Rato, Cetakan ke 2, Hukum Dalam Perspektif Konstruksi Sosial, Yogyakarta: Laksbang Mediatama, 2009.

Esmi Warassih, Pranata Hukum, Semarang: Badan Penerbit Universitas Diponegoro, 2011. FX. Adji Samekto, Justice Not For all, Yogyakarta: Genta Press, 2008.

Hans Kelsen, Teori Hukum Murni, Bandung: Nusa Media. 
Hans Kelsen, Teori Umum Tentang Hukum dan Negara, Bandung: Nusa Media. Ishaq, 2008, Dasar-dasar Ilmu Hukum, Jakarta: Sinar Grarafika, 2011.

Lemhanas, Keadilan Sosial, Jakarta: PT Gramedia Pustaka Utama, 2005.

Moh.Mahfud MD, Politik Hukum di Indonesia, Jakarta: Rajawali Pers, 2012.

Montesquieu, Cetakan Ke 6, The Spirit of Laws, Bandung: Nusa Media, 2013.

Muchsan, Beberapa Catatan Tentang Hukum Administrasi Negara dan Peradilan Administrasi Negara di Indonesia, Yogyakarta: Liberty, 1981.

Muchsan, Sistem Pengawasan Perbuatan Aparat Pemerintah dan Peradilan Tata Usaha Negara, Yogyakarta: Liberty, 2000.

Ni'matul Huda, Otonomi Daerah, Yogyakarta: Pustaka pelajar, 2005.

Rahardjo, Satjipto, Membangun dan Merombak Hukum Indonesia, Yogyakarta: Genta Publishing, 2009.

Saldi Isra, Pergesaran Fungsi Legislasi, Jakarta: Rajawali Pers, 2013.

Salman, Otje dan Susanto, Anton F., Teori Hukum: Mengingat Mengumpulkan, dan Membuka Kembali, Bandung: Refika Aditama, 2013.

Sartjipto Rahardjo, Penegakan Hukum Suatu Tinjauan Sosiologis, Yogyakarta: Genta Publishing, 2009.

Satjipto Rahardjo, Hukum Progresif, Yogyakarta: Genta Publishing, 2009.

Satjipto Rahardjo, Pemanfaatan Ilmu-Ilmu Sosial Bagi Pengembangan Ilmu Hukum, Yogyakarta: Genta Publishing, 2010.

Shidarta, Dardji Darmohardjo, Pokok-Pokok Filsafat Hukum: Apa dan Bagaimana Filsafat Hukum Indonesia, Jakarta: Gramedia Pustaka Utama, 2006.

Sony Keraf, Cetakan 16, Pustaka Filsafat Etika Bisnis, Tuntunan dan Relevansinya, Yogyakarta: Kanisius, 2012.

Sudi Fahmi, Bunga Rampai Pemikiran Hukum di Indonesia, Yogyakarta: FH UII Press, 2009.

Sudikno Mertokusumo, Mengenal Hukum, Yogyakarta: Universitas Atma Jaya Yogyakarta, 2010.

Sudikno Mertokusumo, Cetakan ke 1, Teori Hukum, Yogyakarta: Universitas Atma Jaya, 2011.

Sudikono Mertokusumo, Penemuan Hukum, Yogyakarta: Liberty, 1996.

Syaukani Hr, dkk, Otonomi Daerah dalam Negara Kesatuan, Yogyakarta: Pustaka Pelajar, 2002.

Teori Keadilan: Theo Hujibers, Filsafat Hukum Dalam Lintasan Sejarah, Yogyakarta: Kanisius, 1995.

\section{Journals}

Zainal Asikin, "Divestasi Saham Dalam Perspektif Keadilan (PT. NNT di Nusa Tenggara Barat)", Jurnal IUS, Volume 1, No.1, 2013. 
Erny Yoesry, "Divestasi PT. Freeport Indonesia", Jurnal Hukum \& Pembangunan, No. 1,2019 .

Nelsa Nurfitriani Pratama, et,al, "Pengaturan Kewajiban Divestasi Saham Dalam Perusahaan Modal Asing Di Bidang Pertambangan Menurut PP. No 77 Tahun 2014 Tentang Pelaksanaan Kegiatan Usaha Pertambangan Mineral Dan Batubara", Diponegoro Law Review, Volume 5, No. 2, 2016.

\section{Laws and Regulations}

The 1945 Constitution of the Republic of Indonesia.

Law Number 4 of 2009 concerning Minerals and Coal

Law Number 23 of 2014 regarding Regional Government

Government Regulations No. 23 of 2010 concerning the Implementation of Mineral and Coal Mining Business Activities

\section{Other Sources}

Republika, 2015, NTB minta pusat tegas soal Divestasi saham Newmont, http://www.republika.co.id, accessed 01 Oktober 2020. 